\title{
Database Account Team Management Document
}

National Cancer Institute

\section{Source}

National Cancer Institute. Database Account Team Management Document. NCI

Thesaurus. Code C115687.

Records that contain the management details for team members who require access to a system or database. 